\title{
Taking recovered memories to the court
}

Citation for published version (APA):

Merckelbach, H. L. G. J. (2003). Taking recovered memories to the court. In P. V. Koppen, \& S. D. Penrod (Eds.), Adversarial versus Inquisitorial Justice: Psychological Perspectivers on Criminal Justice Systems (pp. 119-230). Plenum.

Document status and date:

Published: 01/01/2003

Document Version:

Publisher's PDF, also known as Version of record

\section{Please check the document version of this publication:}

- A submitted manuscript is the version of the article upon submission and before peer-review. There can be important differences between the submitted version and the official published version of record.

People interested in the research are advised to contact the author for the final version of the publication, or visit the DOI to the publisher's website.

- The final author version and the galley proof are versions of the publication after peer review.

- The final published version features the final layout of the paper including the volume, issue and page numbers.

Link to publication

\footnotetext{
General rights rights.

- You may freely distribute the URL identifying the publication in the public portal. please follow below link for the End User Agreement:

www.umlib.nl/taverne-license

Take down policy

If you believe that this document breaches copyright please contact us at:

repository@maastrichtuniversity.nl

providing details and we will investigate your claim.
}

Copyright and moral rights for the publications made accessible in the public portal are retained by the authors and/or other copyright owners and it is a condition of accessing publications that users recognise and abide by the legal requirements associated with these

- Users may download and print one copy of any publication from the public portal for the purpose of private study or research.

- You may not further distribute the material or use it for any profit-making activity or commercial gain

If the publication is distributed under the terms of Article $25 \mathrm{fa}$ of the Dutch Copyright Act, indicated by the "Taverne" license above, 


\title{
Taking Recovered Memories to Court
}

\author{
HARALD MERCKELBACH
}

From the outset I want to emphasize that as far as psychological issues are concerned, I do not believe in the superiority of inquisitorial legal systems. To the best of my knowledge, there is no empirical evidence that would justify such a belief. A case in point is the popular argument that in inquisitorial systems, triers of fact are professional judges, who therefore reach better decisions than the lay people who serve as jurors in adversarial systems. Although this argument seems to possess some prima facie validity and is often backed up by anecdotal examples of the O.J. Simpson type of trial, it is not based on compelling evidence. In their classic study, Kalven and Zeisel (1966) found that most of the times, professional judges and lay jurors agree in their verdicts, even if cases and the evidence brought forward are quite complex. Or consider risky shift phenomena and other fiascoes that some authors have thought to be typical for group decisions like those made by jurors. Again, there is no convincing support for the idea that group decisions are necessarily more risky than those made by a single individual (e.g., Aldag \& Riggs Fuller, 1993). Apart from that it is of course quite misleading to assume that in adversarial systems legal decisions are exclusively reached by jury trials. Thus, although there are many cherished myths about adversarial systems and, especially, their reliance on juries, I agree with Sealy (1998) that there is little reason to believe that these myths are grounded in facts.

Having said this, I now turn to the issue of this chapter, which is how adversarial and inquisitorial systems handle recovered memory cases that go to trial. To preview my argument, I propose that the outcome 
of recovered memory cases heavily depends on expert testimony. Under the adversarial regime, parties may recruit their own expert witnesses and may challenge those of their opponents (see for details, Shuman, 1997; Spencer, 1998). In contrast, under the inquisitorial regime, expert witnesses are considered to be the court's witnesses and they are explicitly instructed to behave as such (see for details, Spencer, 1998). Whenever experts testify about technical issues and come from scientific disciplines with a high degree of consensus and precision, it probably doesn't matter much whether one of the parties or the court appoints them (but see Williams, 2000). Things are different with recovered memories. The typical recovered memory case rests on many controversial assumptions. In this particular domain, experts may rely on reasonable hypotheses that are not necessarily correct. If in such cases parties are allowed to choose their own experts, they will not experience much difficulty in finding an expert with an impressive curriculum vitae who fits their partisan purpose. Under an inquisitorial regime, such partisan experts are probably more rare and precisely this state of affairs makes the prospects for successful litigation or prosecution in recovered memory cases not very good.

\section{A PROTOTYPICAL CASE}

Recovered memories refer to recollections of seemingly forgotten childhood events of a traumatic nature (e.g., physical abuse, sexual abuse, severe neglect). In Schooler's (1999, p. 205) words: "an individual who reports recovering a memory for trauma is really indicating two sentiments: (a) that abuse occurred and (b) that there was a period of time in which the memory was not available." A prototypical case would be that of a woman in her late twenties who suffers from a severe depression, an eating disorder, and/or an anxiety disorder. She decides to consult a psychiatrist or psychologist. This clinician has a strong intuition that the woman's psychopathology originates from repressed or dissociated childhood trauma. That is, the clinician believes that the traumatic memories have no access to consciousness, but do produce psychopathological symptoms. $\mathrm{He}$ /she starts using hypnosis or other memory-recovery techniques in order to lift the repression or to circumvent the memory problems caused by dissociation. Eventually, these techniques contribute to the patient's recovery of abuse memories. The patient then decides to bring the recovered memories to court. More specifically, she decides to file a criminal charge and/or a tort damage claim against the perpetrator, who often is a parent.

Case vignettes with this general outline can be found in Loftus and Ketcham (1994), Pendergrast (1995), and Ofshe and Watters (1994), to 
name but a few authors. It would be a mistake to take these case vignettes as caricatures made up by cynical skeptics. Similar and even more spectacular case reports can be found in the writings of those who have no such a reputation. A fine example is a personal experience recounted by hypnotherapist Dabney Ewin (1994). He tells how one day he came home and asked his wife to fix him a cup of coffee. She refused and Ewin experienced an unbridled rage "that was so out of proportion and so unlike me that I felt I had to analyze it" (p. 175). Ewin used self-hypnosis and regressed to the 12 th day of his life. He recovered memories of the day that he was taken off breast-feeding. He adds (p. 175): "The allegory of the woman in my life denying me liquid refreshment is obvious." Apparently, then, the idea that one can apply hypnotic-like techniques to recover memories about the antecedents of behavioral problems is not an invention of skeptics.

The features of our prototypical case also fit well with the basic statistics that have been reported about recovered memory cases (e.g., Gudjonsson, 1997; Van Koppen \& Merckelbach, 1999) and with information provided by so called recanters, that is people who declare that their own recovered memories and the accusations based on them are false (e.g., Lief \& Fetkewicz, 1995). Most importantly, our prototypical case is consistent with data that come from surveys among certified clinicians. For example, a survey of Andrews et al. (1995) among 180 highly trained practitioners of the British Psychological Society found that a majority of them (i.e., 60\%) had seen clients who recovered memories of traumatic incidents. Almost half of the respondents (i.e., $44 \%$ ) believed that these recovered memories were "usually essentially accurate."

\section{WHAT DOES IT MEAN WHEN YOU SAY THAT RECOVERED MEMORIES ARE ESSENTIALLY ACCURATE?}

Although it may be easy for a clinician to tick the "usually" or "always" box in a survey about the accuracy of recovered memories, one should not underestimate the complexity of the issue for an expert witness. When an expert witness testifies that patients' recovered memories are usually correct, he or she really has to believe that the following assumptions refer to facts deserving a place in our psychology textbooks (see for a detailed analysis, Roediger \& Bergman, 1998): (1) total amnesia for traumatic childhood events is a common phenomenon; (2) this phenomenon originates from repression or dissociation, which are processes that store aversive childhood memories in a fixed and indelible format and make them temporarily inaccessible for conscious inspection; and (3) when people somehow succeed in retrieving these previously inaccessible memories, 
they can give a fairly precise report of the content, origins, and temporal characteristics of these memories.

Clearly, each of these assumptions relates to a huge, but also highly controversial corpus of scientific literature (e.g., see for recent reviews, Haber \& Haber, 1998; Ornstein, Ceci, \& Loftus, 1998; Roediger \& Bergman, 1998). Now consider the woman in our prototypical case who seeks criminal prosecution of her biological father or files a civil suit against him on the basis of her recovered memories. Sooner or later, her actions would require expert testimony about the extensive literature on memory and trauma. Her legal prospects would be bad if the expert witness would tell the court that the assumptions listed above lack the status of undisputed facts. Such a conservative position may be expected in a system where the expert is a witness of the court. In contrast, in an adversarial system, the woman's lawyers may shop around for an expert who is willing to adopt a more liberal stance, for example by grounding his or her testimony in what he or she believes to be plausible from a clinical point of view.

A good illustration is provided by the civil trial of Shahzade v. Gregory (1996) that took place in the District of Massachusetts. In this trial, a woman brought suit against her male cousin for damages originating from sexual touching that took place several decades earlier. The woman claimed that she only recently regained the memories of these incidents. Referring to the statute of limitations, her cousin objected to the suit. Nevertheless, a U.S. District Judge ruled that the civil suit could go forward. This decision was heavily based on the testimony of a professor of psychiatry who served as an expert witness for the plaintiff. More specifically, the psychiatrist opined that recovery of traumatic memories from amnesia is a robust phenomenon that is widely accepted by clinicians in the field of psychology and psychiatry. The Boston Globe (April 10, 1996) quotes the psychiatrist as saying that "there is no scientific basis to believe that Shahzade (i.e., the plaintiff) or other victims could fake such memories and fool psychiatric tests."

According to a large-scale survey among psychologists in the United States, 35 percent of them occasionally appear in court to testify (Dawes, 1994). Although I have no precise estimates, I'm quite sure that this percentage is dramatically smaller in a civil (i.e., inquisitorial) law country like the Netherlands. For example, the number of psychologists who on a regular basis present testimony about criminally insane behavior and its legal consequences (in Dutch terbeschikkingstelling) is well below 300 (Malsch, 1998), while the Dutch Psychological Association has more than 10,000 members. The larger the pool of potential expert witnesses, the easier it must be to find an expert willing to testify in a prototypical case that 
recovered memories are usually essentially accurate. This may be particularly true when the expert is hired by the plaintiff and believes that the plaintiff's health may benefit from his or her testimony.

\section{SOME MORE STATISTICS}

In 1996, there were in the United States some 700 lawsuits involving recovered memories at the trial level, while an additional 200 cases reached appellate courts (e.g., Hagen, 1997). For the Netherlands, the best estimate is that in 1996 only 2 or 3 cases involving recovered memories came to the attention of the police, none of them reaching the trial level (Van Koppen \& Merckelbach, 1999). Even if you correct for population size, these statistics demonstrate that there is quite a difference between the United States and the Netherlands in terms of the number of recovered memories cases reaching trial level.

One could reason, of course, that this has to do with different prevalence rates of recovered memories in the two countries. Perhaps, there simply are more recovered memories in the United States than in the Netherlands resulting in more criminal or civil proceedings in the former country. However, this explanation can be refuted on the basis of empirical data. Both countries have so called False Memory Syndrome Foundations. Their members claim that they have been falsely accused on the basis of recovered memories, mostly recovered memories of their daughters. These accusations do not necessarily come to the attention of the police or give rise to a tort damage claim. In the United States, a survey among members of the False Memory Syndrome (FMS) Foundation produced a total of 2,300 accusations (FMS Foundation, 1997). A survey among members of the Dutch counterpart of the False Memory Foundation produced a total of 98 accusations (Van Koppen, 1998). Taking population sizes into account, these rates are roughly comparable to each other, which suggest that there is no difference between the United States and the Netherlands in prevalence rates of recovered memories.

Perhaps, then, the higher frequency of recovered memory cases brought to courts in the United States has to do with specific procedural rules of the American legal system. For example, a number of courts ruled that the "delayed discovery doctrine" known from medical malpractice suits may apply to recovered memory cases as well. Accordingly, statutes of limitation were expanded, allowing plaintiffs with recovered memories to pursue their cases in court some time after their abuse memories were revived. The earlier cited Shazade v. Gregory (1996) trial illustrates this practice. Experts differ sharply in their opinions about whether such 
extensions of the statutory period of limitation are justified by psychological data (see for a discussion, Memon \& Young, 1997). For example, Dorado $(1999$, p. 110) argues that it constitutes "some forward progress for incest survivors hoping to sue their perpetrators." On the other hand, Hagen (1997, p. 254) reminds us that "the crucial difference between genuine discovery cases-" My god, he left the sponge in here!"-and recovered memory of trauma cases is that in the former there is no doubt that the sponge is indeed present in the claimant's body because the poor old claimant had to hire another surgeon to remove the disgusting thing ... But with so-called recovered memory cases, there is often no objective or even supporting evidence that the alleged trauma occurred." However that may be, extension of statutes of limitation creates more opportunities for potential lawsuits and one may speculate that this contributes to the relatively high frequency of lawsuits involving recovered memories in the United States. However, the Netherlands has seen a similar liberalization of statutes of limitations, at least for accusations that involve sexual abuse (i.e., Wet Verlenging Verjaringstermijn Zedenzaken, see Van Koppen, 1998). Interestingly, this reform was partly motivated by the belief that victims often react with amnesia to sexual abuse. Thus, regulations surrounding statutes of limitations do not explain why there are more court cases involving recovered memories in the United States than there are in the Netherlands.

What about the admissibility of clinical testimony in recovered memory cases? In the United States, many courts follow some version of the Daubert decision (Daubert v. Merrell Dow Pharmaceuticals Inc., 1993) to evaluate the admission of scientific expert testimony. The Daubert decision requires a focus on Rule 702 of the Federal Rules of Evidence that emphasizes the helpfulness and relevance of expert testimony to the jury. Some commentators (e.g., Kovera \& Borgida, 1998) have argued that Daubert has lowered the standards for admissibility of expert evidence. For example, the specialized knowledge of expert witnesses mentioned by Rule 702 may also consist of clinical experience. One could hypothesize that this makes admission of clinical expert testimony more likely, which, in turn, may promote lawsuits based on recovered memories. However, as far as criteria for the admissibility of psychological or psychiatric testimony are concerned, the situation in the Netherlands is roughly comparable to that in the United States. In the words of Van Koppen and Saks (2003) who extensively discuss this issue: "As different as the procedures are in the two systems, as we will see, they often are equally ineffective in screening out poor expert evidence." In sum, then, differences in the legal standards for expert psychologists or psychiatrists do not account for the fact that there are more court cases involving recovered memories in the United States than there are in the Netherlands. 


\section{PROFESSIONAL ATTITUDES}

Perhaps, then, it is the attitude of psychiatrists and psychologists towards recovered memories that accounts for the difference. In a country where a majority of psychiatrists and psychologists firmly believe that patients' recovered memories of childhood trauma are usually accurate, it is conceivable that many patients feel encouraged to take legal actions on the basis of their recovered memories. There have been a number of surveys addressing professional attitudes towards recovered memories among clinicians in the United States, the United Kingdom, and the Netherlands (e.g., Merckelbach \& Wessel, 1998; Poole, Lindsay, Memon, \& Bull, 1995; Yapko, 1994). In general, these surveys indicate that there is little reason to believe that skeptics dominate the profession in the Netherlands, whereas believers dominate the profession in the United States or the United Kingdom. For example, one survey (Merckelbach \& Wessel, 1998) found that a majority of Dutch psychotherapists believes that repression of memories is a real phenomenon causing psychopathological symptoms. Yapko (1994) obtained similar findings for American psychotherapists.

Why should there be large differences between Dutch and American professionals to begin with, when they all attend the same conferences and read the same literature? Van der Hart, Boon, and Heijtmajer Jansen (1997, pp. 148-149) provide a lively description of how attitudes and insights are transmitted from one country to another. Referring to Dutch professionals' opinions about Dissociative Identity Disorder (DID; formerly Multiple Personality Disorder), a diagnosis often associated with recovered memories, these authors write: "Since the first workshop on DID in the Netherlands in 1984, given by Dr. Bennett Braun of Chicago, a steadily growing number of Dutch clinicians from all over the country have been diagnosing and treating DID patients." Yet, insights in this research domain may change rapidly. The recent survey by Pope, Oliva, Hudson, Bodkin, and Gruber (1999) among board-certified American psychiatrists revealed that only about one-quarter of them feels that the diagnosis of DID is supported by strong scientific evidence. The psychiatric community in the Netherlands lags behind, because in this country about half of the psychiatrists seems to be in favor of the DID diagnosis (Sno \& Schalken, 1998). Thus, there is no evidence for the idea that nation-wide differences in professional opinions account for the fact that there are more recovered memory trials in the United States than there are in the Netherlands. Moreover, the fact that a sizable minority or even half of the professionals believes in the existence of DID, dissociation, or repression does not automatically imply that these professionals would also be willing 
to mount the witness stand and testify about the essentially accurate quality of recovered memories.

\section{MOUNTING THE WITNESS STAND}

Suppose you are a psychiatrist who has published numerous articles in psychiatric journals about trauma and dissociation and who has treated many patients with such characteristics. And suppose that one day, a lawyer contacts you. He consults you about a patient who recovered memories of childhood abuse during psychotherapy. The patient now wants to bring a criminal charge against her biological father. The lawyer asks you whether you would be willing to testify as an expert witness on behalf of the patient. More specifically, he wants you to inform the court that recovered memories are usually essentially accurate. You decide to interview the lawyer and his client. You learn that there is no independent corroboration for the recovered memories and, of course, you are not surprised: the absence of such evidence is why they asked you in the first place. It also becomes clear to you that the patient has severe dissociative symptoms and that it would come as a great relief to her if her father were sentenced for his offense.

To be sure, you could testify to the court that memories of the sort recovered by the plaintiff are usually essentially correct. In doing so, you could base your opinion on your extensive clinical experience and on scientific literature. As far as the latter is concerned, you could, and probably should, make explicit to the court that your position rests on the three assumptions mentioned earlier. Thus, you may quote from studies that found that a considerable percentage of victims of childhood abuse fail to report the abuse (e.g., Williams, 1994) and you could present this as evidence for the idea that amnesia for childhood trauma is a common phenomenon. You may then go on summarizing a vast literature indicating that trauma promotes repression and dissociative fragmentarization of memories (e.g., Chu, Frey, Ganzel, \& Matthews, 1999). In addition, you may refer to research papers claiming that such traumatic memories, unlike ordinary memories, possess photographic qualities (Van der Kolk, 1994). To make a really impressive case, you could even bring fMRI scans with you. After all, there do exist pictures of the brain that suggest that dissociative patients handle traumatic and neutral memories in qualitatively different ways (e.g., Tsai, Condie, Wu, \& Chang, 1999). Finally, you could point out that there are excellent case studies that illustrate that victims can give well-articulated accounts of the circumstances under which their lost memories turned into recovered memories (Terr, 1984). 
While testimony along these lines is not unreasonable in a clinical conference room, it might be misleading when it is presented in court. Basically, the misleading potential of this testimony has to do with its selective use of the scientific evidence. For example, the fictional expert witness described above fails to inform the court that several review articles have questioned whether amnesia for traumatic events is a common phenomenon (see for a review, Pope, Hudson, Bodkin, \& Oliva, 1998). The expert also ignores studies that have criticized the concept of repression and/or dissociation of traumatic memories (see for reviews, Frankel, 1996; Merckelbach \& Muris, 2001). Likewise, the expert's testimony is silent about studies showing that traumatic memories are not immune for distortions which raises doubts about the photographic qualities of such memories (e.g., Bryant \& Harvey, 1998; Merckelbach, Muris, Horselenberg, \& Rassin, 1998; Roemer, Litz, Orsillo, Ehlich, \& Friedman, 1998). If our expert witness would bring fMRI pictures into the court, that maneuver would be difficult to reconcile with the reservations made by authors like Kulynych (1996). Neuroimages have a certain seductive power because they seem to offer a photographic representation of the brain, when, in fact, they are more similar to highly constructed graphs than to photographic pictures.

The expert in our prototypical case also overlooks findings showing that people are not good in judging the temporal characteristics of their memories. Thus, when a patient or client claims that a traumatic childhood event has not been recalled previously (i.e., before therapy), this may be a false impression (e.g., Loftus, Joslyn, \& Polage, 1998; Parks, 1999). Finally, and perhaps most importantly, our expert runs the risk that his testimony is biased by a tendency to seek and value supportive evidence at the expense of contrary evidence (e.g., Wedding \& Faust, 1989). One potential source of contrary evidence has to do with the fact that the patient recovered memories during psychotherapy. This raises the question whether the memories may have been tainted by treatment. There are a number of studies addressing treatment techniques (e.g., hypnosis, journaling, dream interpretation, imagery) that have the potential to taint memories or to produce complete pseudomemories in patients (e.g., Horselenberg et al., 2000; Hyman, Husband, \& Billings, 1995; Rassin, Merckelbach, \& Spaan, in press). Thus, it would have behooved the expert to tell the court whether or not these studies bear relevance to the case at hand.

\section{CLINICAL VERSUS JUDICIAL DECISION-MAKING}

The problems surrounding expert testimony in recovered memory cases can best be framed in terms of a clash between clinical and judicial 
decision-making (Appelbaum, 1997; Van Koppen \& Saks, 2001; Rassin \& Merckelbach, 1999; Shuman, Stuart, Heilbrun, \& Foote, 1998). Clinical decision-making is based on clinicians $s^{\prime}$ primary obligation to advance their patients' interest. Therefore, doctors must actively look for symptoms and hidden pathology. Indeed, technology in medicine aims at uncovering hidden pathology and the worst error that a clinician can make is that he or she overlooks such pathology. Thus, a good doctor will act according to the principle that absence of evidence is not evidence of absence (of a disease). The doctor's highest priority is preventing false negative outcomes and this occurs when you overlook latent pathology.

Judicial decision-making is quite different. Central to judicial decision-making is not promoting the well-being of the clientele, but seeking and revealing the truth or-somewhat less ambitious-following fair trial principles. Under judicial decision-making rules, the worst error you can make is contributing to the conviction of an innocent suspect. After all, the presumption of innocence is a corner stone of both inquisitorial and adversarial law systems. Accordingly, preventing false positives (i.e., convicting innocent suspects) has high priority in both legal systems.

There can be little doubt that expert witnesses should adopt judicial decision-making heuristics. That is, the expert witness has an obligation to be equally sensitive to the interests of both plaintiffs and suspects and should therefore refrain from partisan testimony. Under an adversarial regime, expert witnesses may find it sometimes difficult to adopt such a role and this may be particularly true for recovered memory cases because here clinicians are often explicitly hired to serve the interests of one party. Under these circumstances, selective use of what is essentially controversial evidence may lead the expert to endorse hypotheses that are reasonable, but not necessarily correct. Such hypotheses, in turn, may constitute the ingredients of partisan testimony.

Under an inquisitorial regime, the expert witness is court-appointed and, therefore, he or she may find it easier to make the transition from clinical to judicial decision-making. This is not to say that unbalanced and partisan expert testimony on recovered memories is totally absent in an inquisitorial law country such as the Netherlands. In fact, we have previously described such testimony by Dutch expert witnesses in detail (e.g., Van Koppen \& Merckelbach, 1998). Interestingly, these civil cases followed an adversarial scenario in that the clinical expert was willing to tell the court that recovered memories are usually essentially correct, thereby showing that he was not able to resist the natural temptation to serve the party that had hired him.

In their thought-provoking review, Lavin and Sales (1998) concluded that it is currently not within the boundaries of a clinician's competence to 
testify that a plaintiff's recovered memory is veridical, even when such testimony is in principle admissible. Nevertheless, offering expert testimony of this sort is far easier when expert witnesses are adversarially called and this may set a premium on filing lawsuits on the basis of recovered memories. Lavin and Sales (1998, p. 77) also noted that "it is appropriate to testify, for example, that there are many reasons to be skeptical about memory reports of long forgotten events." For an expert called and paid by a plaintiff who brings her recovered memories to court, it will be extremely difficult to offer this type of testimony.

Some may argue that in the adversarial system, unbalanced and selective testimony may be corrected through cross-examination by opposing counsels. However, Kovera and Borgida (1998) summarize evidence showing that once jurors have formed beliefs about the reliability of expert testimony, cross-examination does not sensitize jurors to its potential shortcomings. More importantly, it may be precisely because of the adversarial and hostile style of cross-examination that knowledgeable experts may prefer to avoid the courtroom and retreat to their laboratory instead (e.g., Bruck, 1998).

\section{CONCLUSION}

Does this all imply that adversarial legal systems are inferior? No. In the final analysis, the bug in the system is the expert witness, not the adversarial procedure per se. The most obvious solution to the problem of partisan expert testimony is to invite professional organizations to educate their members. Perhaps, such education should start with a demystification of clinical expertise (Dawes, 1994). As the earlier mentioned example of Ewin (1994) illustrates, clinical experience may function as an especially overstated heuristic on which clinical expert witnesses rely. In the words of one skeptic: "Some doctors make the same mistakes for twenty years and call it clinical experience" (Walker, 1996, p. 27).

Good education by professional organizations should also underscore the point that when it comes to traumas and their impact, clinical and judicial domains are not closed circuits. Overstatements in one domain may have their echoes in the other domain. In general terms, it is striking that even recent psychiatric studies in the field of trauma research loosely employ a vocabulary that suggests causality and objective measurement, although they do not reach such standards. Consider the study by Chu et al. (1999). These authors write that "independent corroboration of recovered memories of abuse is often present" (p. 749) when they refer to patients' subjective reports that they (i.e., the patients) had been able to 
find some kind of verification for the abuse. As another example, Lewis, Yeager, Swica, Pincus, and Lewis (1997) claim that their study establishes "once and for all, the linkage between early severe abuse and dissociative identity disorder" (p. 1703), a claim that suggests a large-scale, longitudinal design, when in fact this study was cross-sectional in nature and relied on a sample of 12 patients. A more technical example is provided by a recent study of Draijer and Langeland (1999). Using a cross-sectional design, these authors gathered retrospective self-reports of trauma and dissociation in a clinical sample. The authors concluded that childhood trauma makes a unique contribution to the severity of patients' dissociative symptoms. While this conclusion more or less reiterates the popular view that trauma causes dissociation, it is misleading in that it is premised on a regression analysis in which trauma self-reports entered as the predictor variable and dissociation served as the criterion, a constellation that one could easily reverse (e.g., Merckelbach, Horselenberg, \& Schmidt, in press).

I could go on making a long list of sweeping statements from fairly recent articles that appeared in psychiatric journals, but the message is clear. This type of overstatement may encourage expert witnesses to adopt a partisan attitude. Meanwhile, to educate expert witnesses about the risks of such an attitude is more urgently needed in the United States than in the Netherlands. To the extent that professional organizations do not succeed in disciplining those members who regularly mount the witness stand, the "throw-them-out-of-court" sentiments that were so eloquently articulated by Hagen (1997) become difficult to resist. 